\title{
Spatial and Seasonal Variation in Demersal Trawl Fauna Associated with a Prawn Fishery on the Central Great Barrier Reef, Australia
}

\author{
R. A. Watson ${ }^{\text {A }}$, M. L. C. Dredge ${ }^{\mathrm{B}}$ and D. G. Mayer ${ }^{\mathrm{C}}$ \\ ${ }^{A}$ Northern Fisheries Research Centre, Box 5396, Cairns Mail Centre, Qld 4871, Australia. \\ ${ }^{B}$ Fisheries Research Station, C/- P.O. Burnett Heads, Qld 4670, Australia. \\ C P.O. Box 6014, Rockhampton, Qld 4702, Australia.
}

\begin{abstract}
Regular monthly sampling at eight trawl sites in Great Barrier Reef waters identified variations in both species composition and the relative abundance of the more common species over a 2-year period. Faunal composition was affected more by the location of sample sites than by the time when samples were taken. Ordination analysis differentiated a 'nearshore' group of sites from a 'midshelf' and an 'inter-reef' group. The composition of 'inter-reef' fauna remained strikingly uniform below the $40 \mathrm{~m}$ depth contour regardless of proximity to coral reef formations. Classification of the samples also revealed weakly separated 'wet' and 'dry' season temporal groupings, with the former characterized by higher abundances of several 'nearshore' species.
\end{abstract}

\section{Introduction}

Extensive commercial demersal trawling has continued within areas of the Great Barrier Reef Marine Park despite increasing concern over its effects on fish and invertebrate communities (Sainsbury and Poiner, personal communication). The great diversity of taxa and marine habitats within the Park has made it difficult to create comprehensive checklists for all areas. The scale of seasonal and annual variation in species abundance and community associations is, for the most part, unknown. An understanding of the natural spatial and temporal variability of benthic communities is a basic pre-requisite for deductions on man-induced changes (which include the effects of fishing), the duration of their effects, and the subsequent recovery of the communities (Flint and Younk 1983). To date, this lack of knowledge has made it all but impossible to predict or substantiate the effects of prawn trawling in the Marine Park. Management authorities have therefore zoned the Marine Park for use primarily according to socio-economic considerations that assume an underlying faunal homogeneity and stability.

Previous work on the Central Great Barrier Reef has established that demersal, softbottom faunal assemblages are correlated with sediment type, water depth and distance offshore (Watson and Goeden 1989) but not with the distribution of trawling effort. These site assemblages or zones lie parallel to the coastline, though their boundaries appear to be transitional in nature (Cannon et al. 1987; Watson and Goeden 1989). Similar transitions have been described for other taxa of the Central Great Barrier Reef region. These include hard corals (Done 1982), soft corals (Dinesen 1983), echinoderms and molluscs (Birtles and Arnold 1989), and fishes (Williams 1982). The absence of sample replication and short duration of most of these studies has meant that seasonal or year-to-year effects could not be examined. 
This paper reports fine-scale spatial changes in faunal communities on the Central Great Barrier Reef, as well as variations in species abundance at fixed sites through a consecutive 24-month period. These findings can serve as a basis for comparison with future studies which specifically examine the effects of fishing on the Marine Park.

\section{Materials and Methods}

\section{Study Area}

Trawl sites were chosen in conjunction with a 1985 study (Courtney and Dredge 1988) of an existing prawn fishery on Queensland's continental shelf between $18^{\circ} 30^{\prime} \mathrm{S}$ and $20^{\circ} \mathrm{S}$ (Fig. 1). The initial arrangement of 20 sites sampled during 1985 produced data on the composition of trawlable fauna in a range of water depths, distances from shore and coral reefs, levels of fishing effort and sediment types (Watson and Goeden 1989). In 1986, many of the more southerly sites were eliminated and several northern sites were added (Fig. 1). Seven sites were sampled throughout both years; these represented an inshore to near-reef transect (sites 1-6 and 20). The new sites (21-24) added in 1986 gave a transect with finer spatial resolution from the reef to the midshelf Great Barrier Reef lagoonal environment (sites 21-22-23-6-24-20).

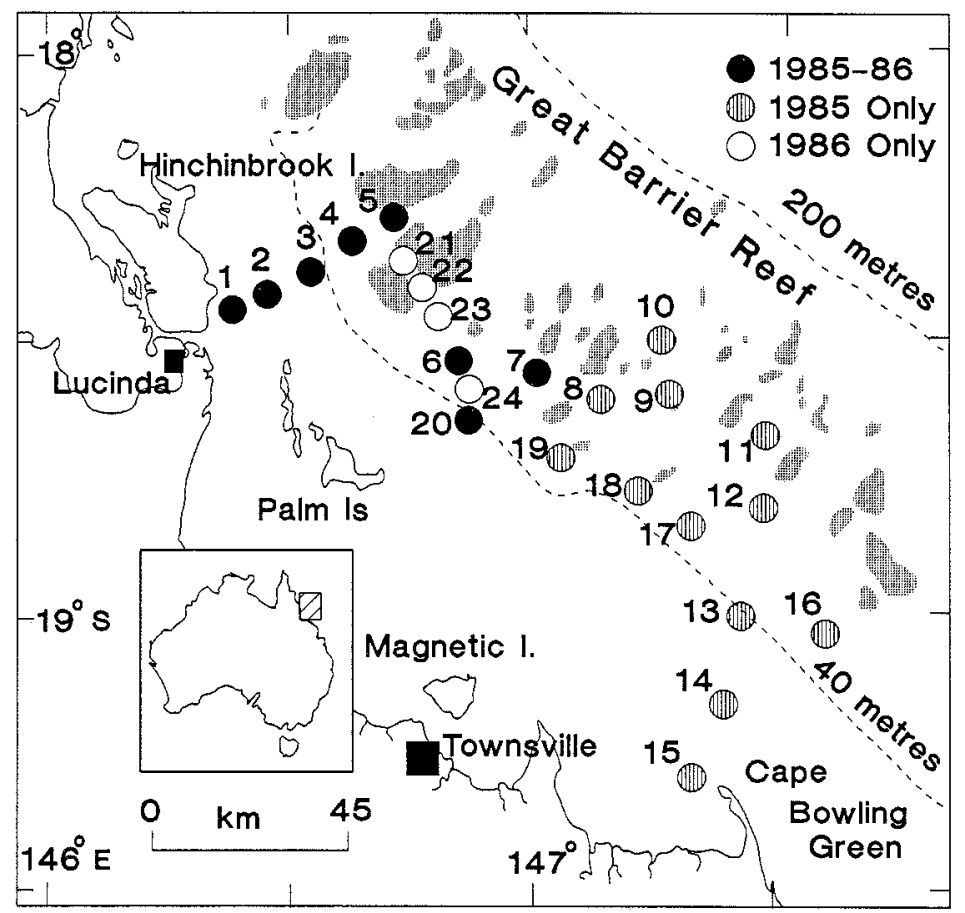

Fig. 1. Location of trawling sample sites.

\section{Sample Collection}

Full details of the sampling methodology are given in Watson and Goeden (1989). Monthly samples of trawlable fauna were obtained between January 1985 and December 1986. All samples were collected within 5 days of the new moon except the May 1985 set, which was delayed by 8 days because of adverse weather. A 19-m vessel was used to trawl along the depth contour for 30 min at $6 \mathrm{~km} \mathrm{~h}^{-1}$ using two 'Florida Flyer' demersal trawl nets, each with a $11-\mathrm{m}$ headline. Samples were taken from the starboard net which was made to standard commercial design (50-mm stretched mesh throughout). The port net, which was made from $40-\mathrm{mm}$ stretched mesh, was used only when the starboard net failed to fish (a total of 12 samples). These samples contributed to the derivation of a checklist of taxa present. 
Sponges, corals, sea snakes, and specimens longer than $1 \mathrm{~m}$ such as stingrays and sharks (which were uncommon in the samples) were noted and discarded. The total catch from the starboard net was weighed and a random subsample of approximately $10 \mathrm{~kg}$ was retained and frozen. In the laboratory, all specimens of Mollusca, Crustacea, Echinodermata, Elasmobranchii and Osteichthyes were identified to species level where possible, or forwarded to the Queensland Museum for identification. Taxa have been listed in Jones and Derbyshire (1988).

Substrate samples were obtained at all sample sites in November 1985 and July 1986, using a small bucket dredge. Sediment size composition was measured and documented after Folk (1974).

\section{Data Analysis}

Species frequencies were calculated, and those present in fewer than $5 \%$ of samples taken in 1985 were omitted from subsequent analysis. To facilitate comparison between trawl samples, the numbers of individuals for the species remaining were standardized as the natural log of the number caught in the starboard net per hour of trawling.

The PATN programme package (Belbin 1988) was used for cluster analysis. Quasi-metric BrayCurtis measures were calculated (Bray and Curtis 1957) and a hierarchic fusion of the matrix was performed using unweighted pair-group arithmetic averages with beta set at -0.1 (Belbin, personal communication) to produce cluster groups. Ordination via multidimensional scaling was used to assist interpretation of temporal and spatial relationships (Faith et al. 1987; Belbin 1988, pp. 194-8). Cramer measures (Lance and Williams 1977) were used to identify species which contributed most significantly to the classification.

Table 1. Position and characteristics of sites sampled in 1986, Great Barrier Reef

\begin{tabular}{rlccccc}
\hline $\begin{array}{c}\text { Site } \\
\text { No. }\end{array}$ & Position & $\begin{array}{c}\text { Depth } \\
(\mathrm{m})\end{array}$ & $\begin{array}{c}\text { Distance } \\
\text { from shore } \\
(\mathrm{km})\end{array}$ & $\begin{array}{c}\text { Proximity to } \\
\text { nearest reef } \\
(\mathrm{km})\end{array}$ & $\begin{array}{c}\text { Mean } \\
\text { particle size } \\
(\phi)\end{array}$ & $\begin{array}{c}\text { Organic } \\
\text { carbon } \\
(\%)^{\mathrm{A}}\end{array}$ \\
\hline 1 & $18^{\circ} 27 \cdot 5^{\prime} \mathrm{S}, 146^{\circ} 22 \cdot 5^{\prime} \mathrm{E}$ & 17 & $4 \cdot 5$ & $31 \cdot 5$ & $6 \cdot 70$ & $8 \cdot 83$ \\
2 & $18^{\circ} 27^{\prime} \mathrm{S}, 146^{\circ} 25 \cdot 5^{\prime} \mathrm{E}$ & 23 & 9 & 26 & $2 \cdot 78$ & $4 \cdot 40$ \\
3 & $18^{\circ} 23^{\prime} \mathrm{S}, 146^{\circ} 32 \cdot 5^{\prime} \mathrm{E}$ & 35 & 20 & 13 & $0 \cdot 93$ & $3 \cdot 51$ \\
4 & $18^{\circ} 20 \cdot 5^{\prime} \mathrm{S}, 146^{\circ} 38^{\prime} \mathrm{E}$ & 42 & $31 \cdot 5$ & $4 \cdot 5$ & $2 \cdot 36$ & $4 \cdot 81$ \\
5 & $18^{\circ} 17 \cdot 5^{\prime} \mathrm{S}, 146^{\circ} 42^{\prime} \mathrm{E}$ & 56 & 40 & 1 & $2 \cdot 63$ & $4 \cdot 97$ \\
6 & $18^{\circ} 28 \cdot 5^{\prime} \mathrm{S}, 146^{\circ} 48^{\prime} \mathrm{E}$ & 53 & 50 & 4 & $2 \cdot 63$ & $4 \cdot 90$ \\
7 & $18^{\circ} 33 \cdot 5^{\prime} \mathrm{S}, 146^{\circ} 58^{\prime} \cdot 5^{\prime} \mathrm{E}$ & 49 & 70 & $4 \cdot 5$ & $1 \cdot 35$ & $5 \cdot 22$ \\
20 & $18^{\circ} 40 \cdot 5^{\prime} \mathrm{S}, 146^{\circ} 52 \cdot 5^{\prime} \mathrm{E}$ & 44 & $53 \cdot 5$ & $17 \cdot 5$ & $1 \cdot 88$ & $4 \cdot 09$ \\
21 & $18^{\circ} 19 \cdot 5^{\prime} \mathrm{S}, 146^{\circ} 40^{\prime} \mathrm{E}$ & 44 & 35 & 3 & $1 \cdot 69$ & $3 \cdot 79$ \\
22 & $18^{\circ} 22 \cdot 5^{\prime} \mathrm{S}, 146^{\circ} 43^{\prime} \mathrm{E}$ & 49 & $40 \cdot 5$ & $0 \cdot 5$ & $1 \cdot 97$ & $5 \cdot 32$ \\
23 & $18^{\circ} 26^{\prime} \mathrm{S}, 146^{\circ} 47^{\prime} \mathrm{E}$ & 53 & 48 & $2 \cdot 5$ & $2 \cdot 85$ & $4 \cdot 19$ \\
24 & $18^{\circ} 33^{\prime} \mathrm{S}, 146^{\circ} 48^{\prime} \mathrm{E}$ & 43 & 50 & 10 & $1 \cdot 71$ & $4 \cdot 76$ \\
\hline
\end{tabular}

A After J. W. A. Robertson (unpublished data).

\section{Results}

\section{Sample Site Data}

Details of sample site position, depth, distance from shore and nearest coral reef, mean substrate particle size and organic carbon content are given in Table 1. Sediments from inshore sites were characterized by fine particle size and high organic content, possibly of terrigenous origin. Sample sites in the midshelf and near-reef areas had substrates with larger grain size and lower organic carbon content; these may have been of biogenic origin. Depth, distance from shore and mean particle size of sediments were confounded characteristics of the sample sites (Table 1). 
Fauna

Specimens collected from January 1985 to December 1986 represented nine phyla, 18 classes, 158 families and 477 species or species complexes (Jones and Derbyshire 1988). The majority of species were represented by only a few individuals. Fewer than 15 species represented over $80 \%$ of all individuals collected (Fig. 2).

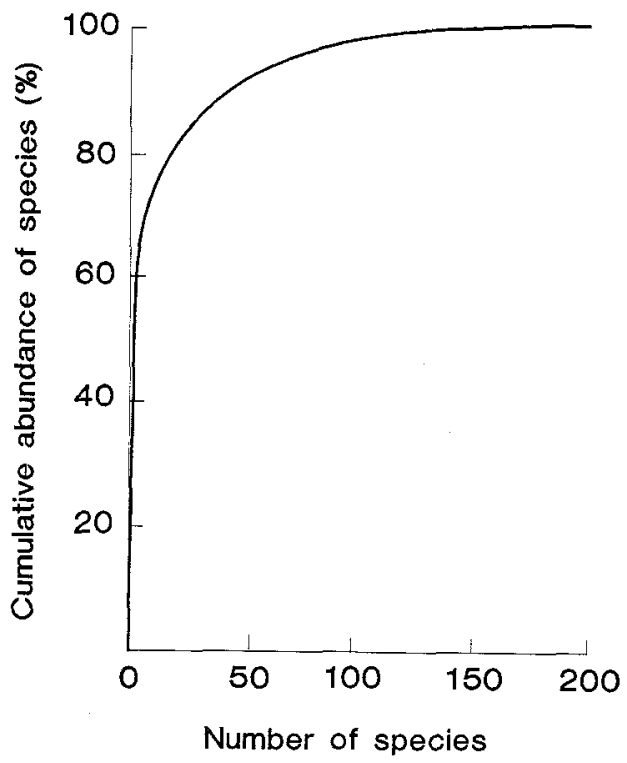

Fig. 2. Relationship between the cumulative abundance of all animals sampled (\%) and the number of species.

Table 2. Percentage breakdown of demersal trawl fauna by class, based on numbers of individuals

\begin{tabular}{llrr}
\hline \multicolumn{1}{c}{ Phylum } & \multicolumn{1}{c}{ Class } & 1985 & 1986 \\
\hline Chordata & Ascidiacea & 1 & $<1$ \\
& Osteichthyes & 41 & 34 \\
Arthropoda & Crustacea & 39 & 54 \\
Echinodermata & Crinoidea & $<1$ & $<1$ \\
& Asteroidea & 1 & $<1$ \\
& Ophiuroidea & $<1$ & $<1$ \\
& Echinoidea & 16 & 7 \\
& Holothuroidea & $<1$ & $<1$ \\
Mollusca & Gastropoda & $<1$ & $<1$ \\
& Bivalvia & 3 & 3 \\
& Cephalopoda & 1 & 1 \\
\hline
\end{tabular}

The gross composition of trawl by-catch from common sites sampled in 1985 and 1986 varied considerably. The percentage of individuals in Crustacea increased in 1986 while the percentage in Osteichthyes and Echinoidea decreased (Table 2). Other classes of trawl fauna were essentially unchanged.

The twelve most abundant species have been ranked by abundance in the 1985 and 1986 samples (Table 3). There were some differences in these rankings between years. Numbers in both years were dominated by crustaceans, particularly the non-commercial prawns (Metapenaeopsis spp. and Trachypenaeus spp.); however, in 1985 the flatfish 
Table 3. Twelve most numerous species in demersal trawl fauna (ranked by numerical order in 1985)

\begin{tabular}{lrr}
\hline \multicolumn{1}{c}{ Species } & \multicolumn{2}{c}{ Rank } \\
& 1985 & 1986 \\
\hline Metapenaeopsis spp. (Crustacea) & 1 & 1 \\
Maretia planulata (Echinodermata) & 2 & 4 \\
Engyprosopon grandisquama (Osteichthyes) & 3 & 7 \\
Trachypenaeus spp. (Crustacea) & 4 & 3 \\
Portunus tenuipes (Crustacea) & 5 & 2 \\
Paramonacanthus japonicus (Osteichthyes) & 6 & 6 \\
Upeneus sp. 1 (Osteichthyes) & 7 & 9 \\
Amusium balloti (Mollusca) & 8 & 10 \\
Portunus rubromarginatus (Crustacea) & 9 & 13 \\
Lepidotrigla calodactyla (Osteichthyes) & 10 & 16 \\
Portunus argentatus (Crustacea) & 11 & 8 \\
Nemipterus celebicus (Osteichthyes) & 12 & 5 \\
\hline
\end{tabular}

Engyprosopon grandisquama and the urchin Maretia planulata were amongst the three highest ranking species. These species were ranked 4th and 7th in abundance in 1986.

\section{Temporal v. Spatial Effects}

Ordination of all samples taken during 1986 revealed three major cluster groups (Fig. 3), These groups were: all samples taken at nearshore site 1 (group 1), those taken at site 2 (group 2), and those taken elsewhere. Spatial effects were therefore far more important than temporal effects in the formation of cluster groups. The classification of sites was, on the

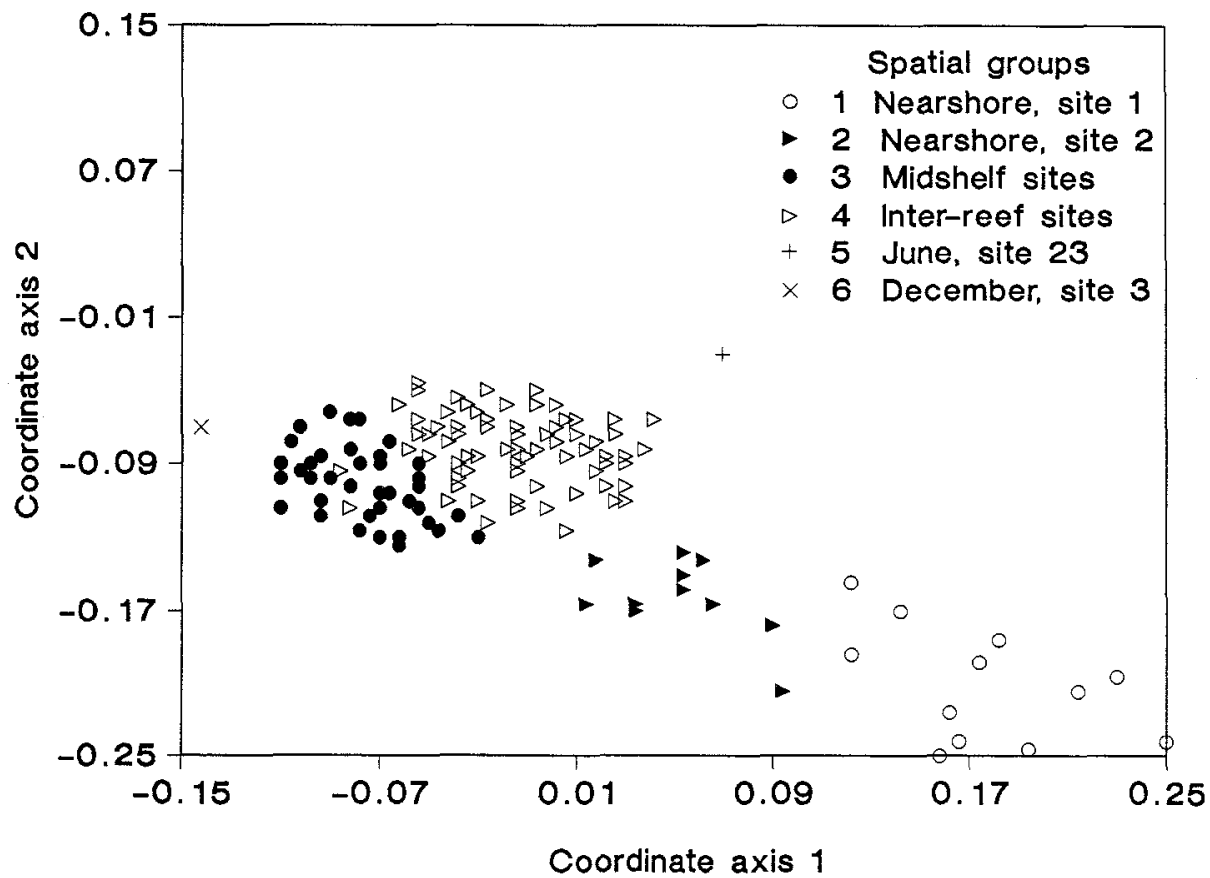

Fig. 3. Ordination of 1986 samples showing spatial and temporal relationships. 
Table 4. Summary of results of temporal/spatial analysis of 1986 samples at trawl sites Cluster groups represented by their group number (1-4), singleton groups represented by $\mathrm{x}$, missing samples by blanks

\begin{tabular}{|c|c|c|c|c|c|c|c|c|c|c|c|c|}
\hline \multirow[t]{2}{*}{ Month } & \multicolumn{12}{|c|}{ Site } \\
\hline & 1 & 2 & 3 & 4 & 5 & 6 & 7 & 20 & 21 & 22 & 23 & 24 \\
\hline Jan. & 1 & 2 & 3 & 3 & 4 & 4 & & 3 & 3 & 4 & 4 & 3 \\
\hline Feb. & 1 & 2 & 3 & 3 & 4 & 4 & & 3 & 4 & 4 & 4 & 4 \\
\hline Mar. & 1 & 2 & 3 & 4 & 4 & 4 & & 3 & 4 & 4 & 4 & 4 \\
\hline Apr. & 1 & 2 & 3 & 4 & 4 & 4 & & 3 & 4 & 4 & 4 & 4 \\
\hline May & 1 & 2 & 3 & 4 & 4 & 4 & & 3 & 4 & 4 & 4 & 4 \\
\hline June & 1 & 2 & 3 & 3 & 4 & 4 & 3 & 3 & 4 & & $\mathrm{x}$ & 4 \\
\hline July & 1 & 2 & 3 & 4 & 4 & 4 & 3 & 3 & 4 & 4 & 4 & 4 \\
\hline Aug. & 1 & 2 & 3 & 4 & 4 & 4 & 3 & 3 & 4 & 4 & 4 & 3 \\
\hline Sept. & 1 & & 3 & 3 & 4 & 4 & & 3 & 4 & 4 & 4 & 4 \\
\hline Oct. & 1 & 2 & 3 & 4 & 4 & 4 & 3 & 3 & 4 & 4 & 4 & 3 \\
\hline Nov. & 1 & 2 & 3 & 3 & 4 & 4 & 3 & 3 & 3 & & 4 & 3 \\
\hline Dec. & 1 & 2 & $\mathrm{x}$ & 4 & 4 & 4 & & & 4 & 4 & 4 & 4 \\
\hline
\end{tabular}

whole, consistent throughout the year of study (Table 4). Removal of the nearshore sites 1 and 2, which dominated the analysis, revealed two other major groupings. Sites 3, 7 and 20, all midshelf sites, consistently grouped together (group 3). The inter-reef sites 5, 6 and 21-23 formed a second group (group 4; Figs 3 and 4). Two sites (4 and 24) did not group consistently throughout the year. In some months these sites were associated with the midshelf group, and in others with the inter-reef group. After the manner of Watson

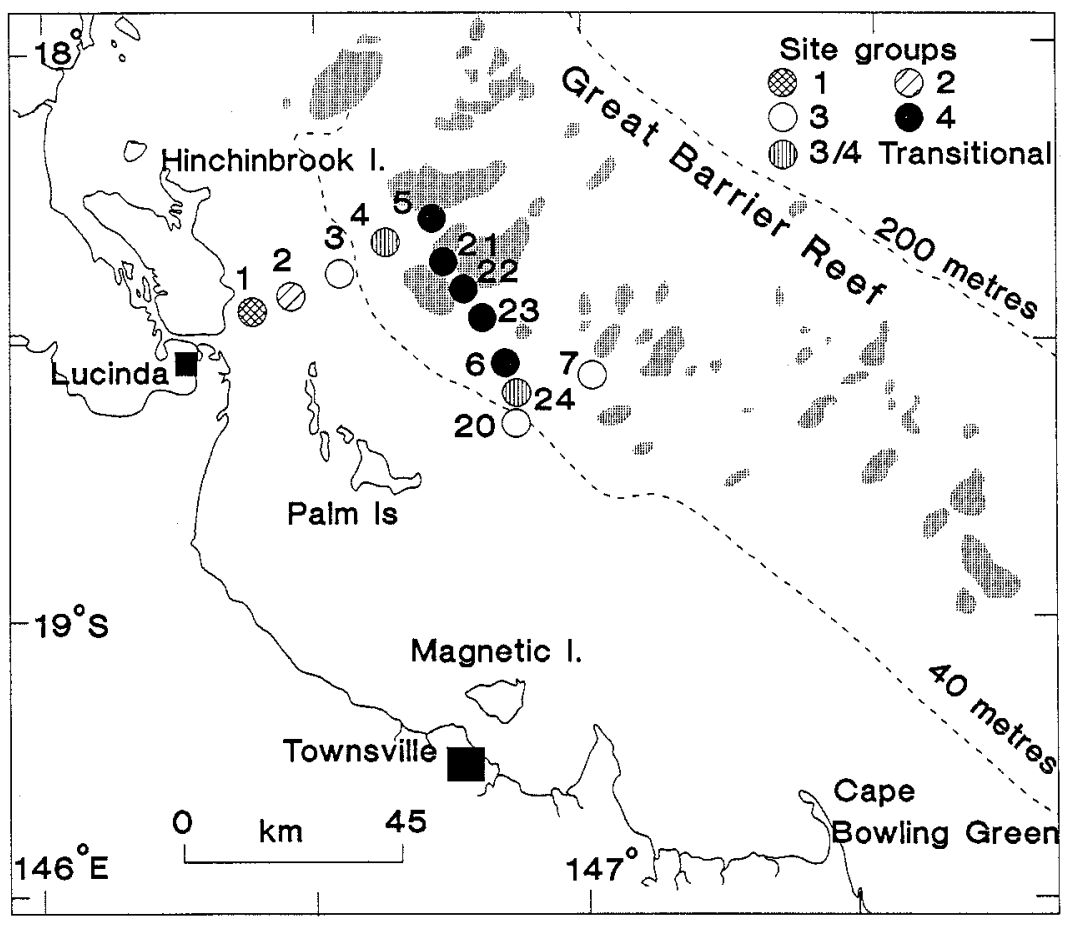

Fig. 4. Classification of trawling sites into site groups. 
Table 5. Species characteristic of temporal/spatial groups in demersal trawl fauna (C) Crustacea, (O) Osteichthyes and (M) Mollusca

\begin{tabular}{|c|c|c|c|c|c|c|c|c|}
\hline \multirow[t]{2}{*}{ Species } & \multirow{2}{*}{$\begin{array}{c}\text { Cramer } \\
\text { value }\end{array}$} & \multirow{2}{*}{$\begin{array}{c}F \\
\text { value }\end{array}$} & \multicolumn{6}{|c|}{ Log of mean catch rate in each group } \\
\hline & & & 1 & 2 & 3 & 4 & 5 & 6 \\
\hline (O) Nemipterus celebicus & 0.91 & $123 \cdot 30$ & - & $0 \cdot 76$ & $4 \cdot 34$ & $4 \cdot 99$ & - & $6 \cdot 04$ \\
\hline (O) Epinephelus sexfasciatus & 0.88 & $84 \cdot 96$ & $1 \cdot 52$ & $2 \cdot 38$ & - & - & - & - \\
\hline (O) Pomadasys trifasciata & 0.85 & $65 \cdot 58$ & $2 \cdot 10$ & $0 \cdot 10$ & - & - & - & - \\
\hline (C) Portunus tenuipes & 0.85 & $65 \cdot 40$ & - & $1 \cdot 30$ & $4 \cdot 30$ & $5 \cdot 69$ & $3 \cdot 61$ & $5 \cdot 09$ \\
\hline (C) Metapenaeopsis spp. & 0.84 & $63 \cdot 33$ & $1 \cdot 52$ & $1 \cdot 55$ & $6 \cdot 00$ & $6 \cdot 39$ & $3 \cdot 66$ & - \\
\hline (O) Saurida tumbil & 0.84 & $62 \cdot 32$ & $2 \cdot 73$ & 0.45 & - & 0.09 & - & - \\
\hline (O) Upeneus sundiacus & 0.82 & $53 \cdot 13$ & - & $1 \cdot 96$ & - & - & - & - \\
\hline (C) Penaeus semisulcatus & 0.82 & $52 \cdot 39$ & $1 \cdot 85$ & $1 \cdot 94$ & - & - & - & - \\
\hline (O) Apogon quadrifasciatus & 0.82 & $51 \cdot 46$ & $4 \cdot 22$ & $2 \cdot 03$ & 0.38 & $0 \cdot 17$ & - & - \\
\hline (O) Pseudorhombus elevatus & 0.81 & $47 \cdot 53$ & $2 \cdot 03$ & $3 \cdot 45$ & $0 \cdot 18$ & $0 \cdot 11$ & $1 \cdot 61$ & - \\
\hline (O) Apogon poecilopterus & 0.80 & $45 \cdot 61$ & $3 \cdot 76$ & $2 \cdot 16$ & $0 \cdot 15$ & $0 \cdot 25$ & - & - \\
\hline (O) Portunus argentatus & 0.78 & $40 \cdot 69$ & $0 \cdot 13$ & - & 0.78 & $4 \cdot 26$ & $3 \cdot 22$ & - \\
\hline (C) Penaeus longistylus & 0.77 & $37 \cdot 85$ & - & - & $4 \cdot 06$ & $3 \cdot 51$ & - & $4 \cdot 17$ \\
\hline (O) Parapercis nebulosa & 0.76 & $34 \cdot 83$ & - & - & $3 \cdot 73$ & $2 \cdot 17$ & - & - \\
\hline (O) Repomuscenus belcheri & 0.75 & $33 \cdot 50$ & $1 \cdot 25$ & $3 \cdot 91$ & 0.50 & $0 \cdot 11$ & - & - \\
\hline (O) Minous versicolor & 0.75 & $33 \cdot 45$ & - & - & - & 0.09 & - & $4 \cdot 17$ \\
\hline (O) Scolopsis taeniopterus & $0 \cdot 74$ & $31 \cdot 36$ & - & $2 \cdot 28$ & - & $0 \cdot 03$ & - & - \\
\hline (O) Euristhmus nudiceps & 0.74 & $30 \cdot 58$ & 0.09 & $3 \cdot 05$ & - & 0.43 & - & - \\
\hline (O) Terapon theraps & $0 \cdot 73$ & $28 \cdot 17$ & $1 \cdot 76$ & $1 \cdot 31$ & 0.06 & - & - & - \\
\hline (O) Paramonacanthus japonicus & $0 \cdot 72$ & $27 \cdot 42$ & $0 \cdot 13$ & $1 \cdot 60$ & $4 \cdot 54$ & $3 \cdot 87$ & $1 \cdot 10$ & $7 \cdot 21$ \\
\hline (C) Charybdis truncata & 0.72 & $27 \cdot 28$ & $5 \cdot 16$ & $4 \cdot 03$ & 0.62 & $1 \cdot 37$ & - & - \\
\hline (O) Nemipterus hexodon & 0.72 & $26 \cdot 61$ & $2 \cdot 70$ & $2 \cdot 13$ & $0 \cdot 34$ & $0 \cdot 13$ & - & $3 \cdot 50$ \\
\hline (M) Amusium pleuronectes & 0.71 & $26 \cdot 53$ & $1 \cdot 47$ & $3 \cdot 12$ & 0.05 & $0 \cdot 17$ & - & - \\
\hline (O) Torquigener whitelyi & 0.71 & $25 \cdot 23$ & 0.83 & $2 \cdot 13$ & - & - & - & - \\
\hline (O) Orbonymus rameus & $0 \cdot 70$ & $24 \cdot 61$ & - & - & $2 \cdot 71$ & $0 \cdot 32$ & - & - \\
\hline
\end{tabular}

and Goeden (1989), these sites could be described as transitional in nature. They were geographically positioned between those which grouped consistently with the midshelf group, and those in the inter-reef group (Fig. 4). There were also two samples collected in 1986, one in June (site 23, group 5; Fig. 3) and the other in December (site 3, group 6; Fig. 3), which formed singleton groups. The June 1986 sample at site 23 was exceptionally small $(2 \mathrm{~kg})$; hence, the entire catch formed the sample for that month. The small catch could have resulted from partial failure of the trawl gear. The weight of the total catch of the December 1986 sample from site 3 was unusually high at $153 \mathrm{~kg}$.

These largely spatial groups have been characterized by those species most important in their formation on the basis of Cramer measures (Table 5). Group 1 (site 1) had large numbers of Pomadasys trifasciata and Saurida tumbil which were rare elsewhere, whereas group 2 (site 2) samples had large numbers of several species including: Upeneus sundiacus, Repomuscenus belcheri, Scolopsis taeniopterus, Euristhmus nudiceps, Amusium pleuronectes and Torquigener whitelyi (Table 5).

In addition to these species, the two nearshore groups also had much higher numbers of Epinephelus sexfasciatus, Penaeus semisulcatus (grooved tiger prawn), Terapon theraps, and Charybdis truncata than those groups which represented of fshore sites (Table 5).

Compared with the nearshore sites, the offshore sites (groups 3 and 4; Table 5) had high numbers of the fish Nemipterus celebicus, Parapercis nebulosa and Paramonacanthus japonicus. The crustaceans Metapenaeopsis spp. (coral prawns), Penaeus longistylus (red spot king prawn) and Portunus tenuipes were also relatively more abundant at the offshore sites than at the inshore sites. The inter-reef group had characteristically high numbers of the crab Portunus argentatus compared with the nearshore sites. 
The singleton groups 5 and 6 came from trawl samples dominated by high numbers of relatively few species such as $N$. celebicus and $P$. japonicus (Table 5).

\section{Temporal Effects}

Temporal effects were examined by classification. Data from the seven sites which were sampled throughout 1985 and 1986 were grouped from each month's samples to give 24 entities. This process revealed cluster groups of sample months (Fig. 5) that demonstrated

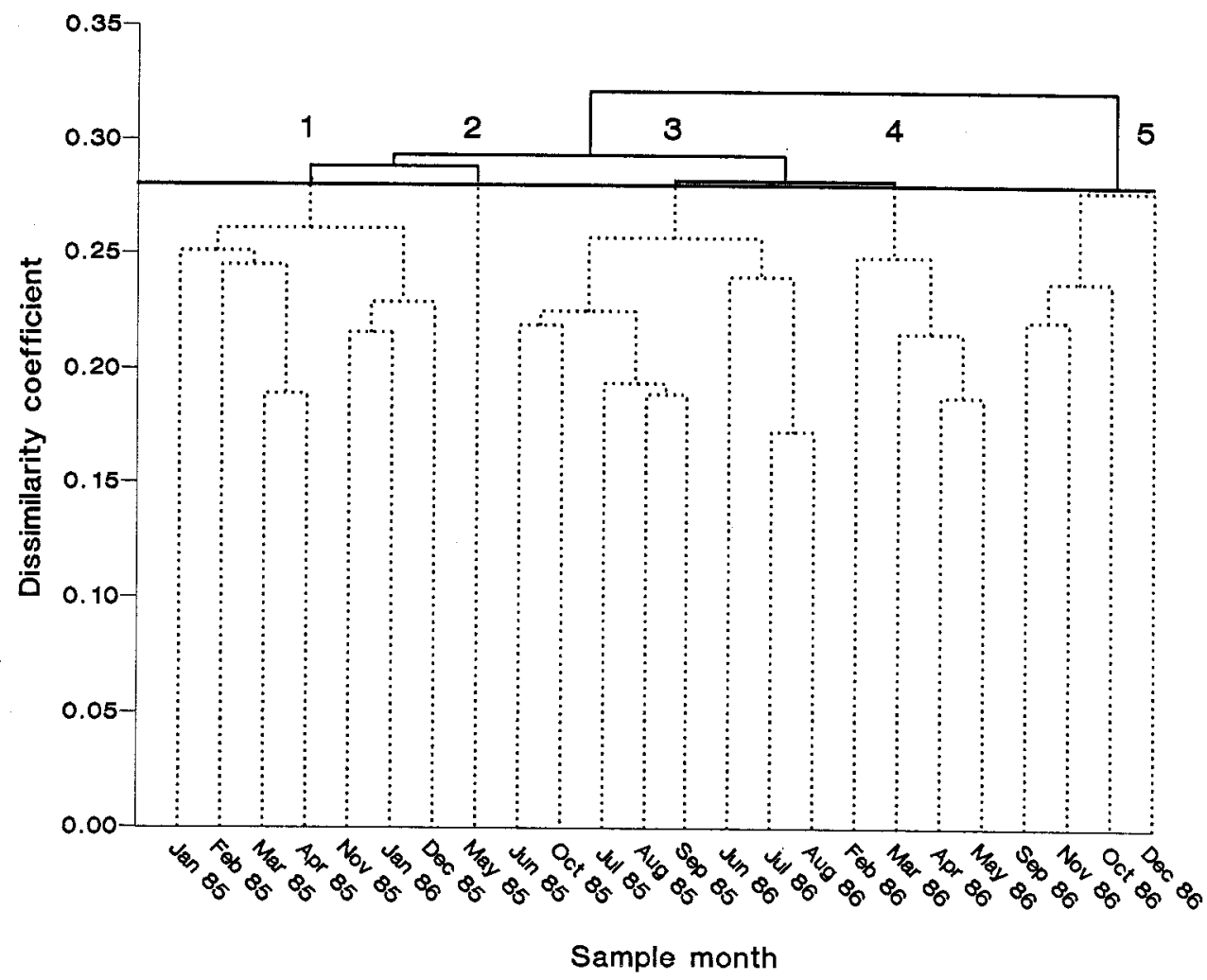

Fig. 5. Temporal relationships from summation of fauna from all sites sampled over 24 months.

both seasonal and inter-annual trends (Fig. 6). Five groups were identified: January-April 1985 and December 1985-January 1986 (group 1); May 1985 (group 2); June-October 1985 and July-August 1986 (group 3); February-May 1986 (group 4); and September-December 1986 (group 5). These could be further characterized as two 'wet' season groups (groups 1 and 4; Fig. 6) that occurred approximately from late December to April, and two 'dry' season groups (groups 3 and 5; Fig. 6). Samples from similar monthly periods from the two sample years formed similar, yet separate, groups. Temporal group 2 consisted only of May 1985.

These temporal groups are again characterized by their contributing species according to their derived Cramer values (Table 6). Samples taken during May 1985 (group 2) had greater abundances of Upeneus sulphureus and Tetrosomus gibbosus than at other times (Table 6). Three scorpaenid species: Tetraroge leucogaster, Minous trachycephalus and Inimicus caledonicus were not present in these samples, while present at all other sampling occasions. Metapenaeopsis spp. were relatively less abundant in group 2 than in all other temporal groups. 


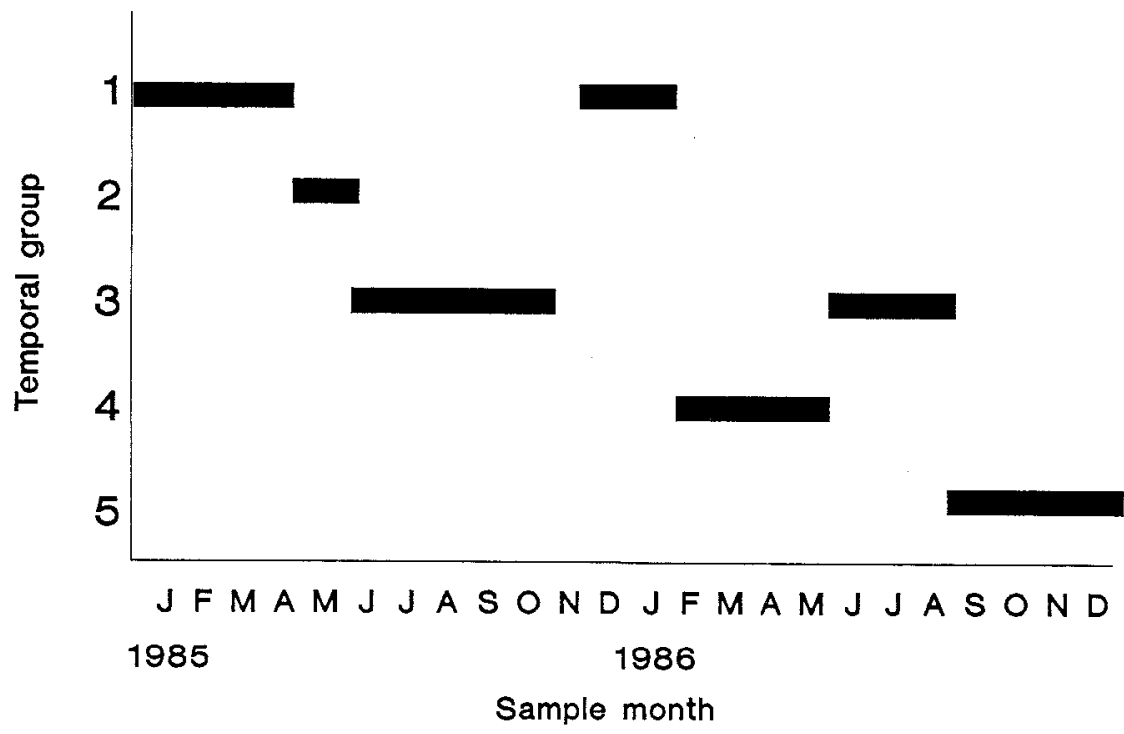

Fig. 6. Time chart showing temporal relationships for the 24-month period 1985-86.

Table 6. Species characteristic of temporal groups in demersal trawl fauna (C) Crustacea, (E) Echinodermata, (O) Osteichthyes and (M) Mollusca

\begin{tabular}{|c|c|c|c|c|c|c|c|}
\hline \multirow[t]{2}{*}{ Species } & \multirow{2}{*}{$\begin{array}{l}\text { Cramer } \\
\text { value }\end{array}$} & \multirow{2}{*}{$\begin{array}{c}F \\
\text { Value }\end{array}$} & \multicolumn{2}{|c|}{ Log of mean } & \multicolumn{2}{|c|}{ atch rate in each } & \multirow{2}{*}{$\begin{array}{c}\text { group } \\
5\end{array}$} \\
\hline & & & 1 & 2 & 3 & 4 & \\
\hline (O) Samaris cristatus & 0.87 & $14 \cdot 28$ & $0 \cdot 23$ & - & $0 \cdot 17$ & 0.51 & 0.95 \\
\hline (C) Portunus rubromarginatus & 0.86 & $14 \cdot 04$ & $1 \cdot 64$ & $2 \cdot 60$ & $2 \cdot 86$ & $3 \cdot 10$ & $2 \cdot 04$ \\
\hline (O) Nemipterus tolu & 0.81 & $9 \cdot 15$ & $0 \cdot 40$ & 0.64 & $0 \cdot 52$ & $1 \cdot 80$ & $0 \cdot 14$ \\
\hline (O) Upeneus tragula & $0 \cdot 79$ & $8 \cdot 04$ & $0 \cdot 32$ & 0.57 & $1 \cdot 51$ & 0.51 & 0.98 \\
\hline (C) Portunus gracilimanus & 0.79 & $8 \cdot 00$ & 0.64 & $1 \cdot 41$ & 0.47 & $1 \cdot 11$ & - \\
\hline (C) Metapenaeopsis spp. & 0.78 & $7 \cdot 40$ & $4 \cdot 79$ & $2 \cdot 85$ & $4 \cdot 47$ & $4 \cdot 16$ & $5 \cdot 07$ \\
\hline (C) Portunus pelagicus & $0 \cdot 77$ & $7 \cdot 11$ & 0.85 & 0.26 & $0 \cdot 44$ & $1 \cdot 46$ & $0 \cdot 19$ \\
\hline (O) Parapercis nebulosa & $0 \cdot 76$ & $6 \cdot 31$ & $1 \cdot 17$ & $1 \cdot 62$ & $1 \cdot 86$ & $2 \cdot 54$ & $1 \cdot 65$ \\
\hline (O) Tetrosomus gibbosus & $0 \cdot 75$ & $6 \cdot 16$ & - & $0 \cdot 34$ & - & 0.09 & - \\
\hline (E) Stellaster equestris & $0 \cdot 75$ & $6 \cdot 12$ & $0 \cdot 28$ & $1 \cdot 54$ & $0 \cdot 18$ & $0 \cdot 30$ & 0.53 \\
\hline (O) Pseudorhombus spinosus & 0.75 & $6 \cdot 02$ & $2 \cdot 22$ & $1 \cdot 78$ & $1 \cdot 74$ & $2 \cdot 48$ & $1 \cdot 34$ \\
\hline (C) Trachypenaeus spp. & 0.74 & $5 \cdot 78$ & $4 \cdot 15$ & 1.90 & $4 \cdot 53$ & $4 \cdot 87$ & $3 \cdot 89$ \\
\hline (O) Tetraroge leucogaster & $0 \cdot 74$ & $5 \cdot 69$ & 0.04 & - & 0.75 & 0.47 & $0 \cdot 37$ \\
\hline (O) Dactyloptena papilo & 0.74 & $5 \cdot 64$ & $1 \cdot 72$ & $2 \cdot 95$ & $1 \cdot 76$ & 0.90 & $0 \cdot 44$ \\
\hline (M) Amusium pleuronectes & 0.73 & $5 \cdot 35$ & $1 \cdot 18$ & 0.26 & 0.59 & $1 \cdot 29$ & 0.72 \\
\hline (O) Engyprosopon grandisquama & $0 \cdot 72$ & $5 \cdot 24$ & $3 \cdot 35$ & $3 \cdot 11$ & $3 \cdot 83$ & $4 \cdot 02$ & $2 \cdot 95$ \\
\hline (C) Charybdis truncata & $0 \cdot 72$ & $5 \cdot 00$ & $1 \cdot 95$ & $2 \cdot 46$ & $1 \cdot 43$ & $2 \cdot 83$ & $1 \cdot 49$ \\
\hline (O) Minous trachycephalus & $0 \cdot 71$ & $4 \cdot 94$ & $0 \cdot 22$ & - & $1 \cdot 08$ & 0.66 & 0.85 \\
\hline (O) Inimicus caledonicus & $0 \cdot 70$ & $4 \cdot 61$ & $0 \cdot 73$ & - & $1 \cdot 28$ & 0.57 & 0.64 \\
\hline (O) Upeneus sulphureus & $0 \cdot 70$ & $4 \cdot 58$ & 0.68 & $2 \cdot 20$ & $0 \cdot 76$ & 0.48 & $0 \cdot 18$ \\
\hline (O) Euristhmus nudiceps & $0 \cdot 70$ & $4 \cdot 55$ & 0.29 & $0 \cdot 26$ & 0.60 & 0.92 & 0.56 \\
\hline (O) Terapon theraps & 0.70 & $4 \cdot 48$ & 0.89 & 1.89 & 0.43 & 0.76 & 0.26 \\
\hline
\end{tabular}

\section{Discussion}

The faunal assemblage sampled in this study was tropical western Pacific in affinity and dominated by small fishes (Jones and Derbyshire 1988). Few studies of the Great Barrier Reef region have included all the faunal groups included in Table 2 but it appears 
that this breakdown may be typical of the tropical north-eastern Australian coastal waters. Some crustacean species were the most numerous taxa in the trawl catch. Species of Metapenaeopsis and Portunus were also found to be abundant on the tropical continental shelf of north-western Australia (Ward and Rainer 1988).

The major change in the breakdown of taxa by class between 1985 and 1986 was the proportionate increase of crustacean abundance, and corresponding decrease in bony fishes and echinoderms (Table 2 ). The crustacean species which were relatively more abundant in 1986 included the portunid $P$. tenuipes, and prawns in the genus Trachypenaeus (Table 3). The echinoderm $M$. planulata and the flatfish $E$. grandisquama were relatively less abundant in the by-catch between 1985 and 1986. Catches of $M$. planulata were erratic and our samples showed that it was clumped in distribution. Jones and Derbyshire (1988) found that it was discontinuously very numerous and sometimes dominated the trawl catch. They did not believe that its occurrence represented a static ' $M$. planulata' community.

There was some evidence of interannual faunal variation (Tables 2 and 3). Unfortunately, two years' data are not likely to characterize the normal extent of interannual variation. We concur with Flint and Younk (1983) who found that the literature included few longterm data sets with which to evaluate the normal dynamics of benthic communities over extended periods. Williams (1986) found that the largest interannual variation in reef fish communities was no greater than the observed inter-reef variability at a particular time. He suggested that some species may be inherently more variable than others and that this was in part due to a year-to-year variability in recruitment (Williams 1982). Riesen and Reise (1982) found that substantial changes had occurred in the faunal composition at sites revisited after 55 years, and attributed these to human interference. Rainer (1984) reported that the relative abundances of dominant species varied substantially over seasons and suggested that this probably occurred over longer periods as well. In general, benthic faunal distributions may vary considerably in time and space. This may be a consequence of variation in recruitment, of patchy species occurrence related to the overall heterogeneity of the benthic habitat such as variability in bottom sediment and man-induced effects (Flint and Younk 1983), or of chance occurrences, as has been suggested by Sale (1978) for some reef-dwelling fish.

In the present study, spatial variation was much more pronounced than seasonal variation. Flint and Younk (1983) also concluded that spatial variability was much greater than temporal variability for benthic communities. Williams et al. (1988) found that almost all taxa of larval fish showed significant station $\times$ cruise interactions. Spatially dependent physical factors such as water depth and topographical complexity had more effect on coral reef fish communities than did temporal effects such as variability in their recruitment (Williams 1982). Williams (1986) reported that differences in fish species abundances between reefs within a shelf location (localized spatial effects) were similar to, or greater than, temporal variation within reefs but were much less than differences across the continental shelf (large-scale spatial effects).

This study showed clear differences between the two nearshore sites (sites 1 and 2, Fig. 4). These were, however, grouped together in the 'coastal' site assemblage in a previous study (Watson and Goeden 1989). Watson and Goeden's study, based on sites samples in 1985 (Fig. 1), covered greater geographical range but spatial resolution in the proximity of the reef was poorer. The use of a range of sites $(21-23,6,24$ and $20 ; \mathrm{Fig}$. 4) that grade away from the reef was intended to determine whether an assemblage more closely related to that of the reef itself existed in close proximity to the reef. Instead, this series of sites demonstrated how similar the inter-reef fauna remains, regardless of proximity to the reef, in the depth range of $40-55 \mathrm{~m}$ and an off-reef distance of 0.5 to $10 \mathrm{~km}$ (Fig. 4).

The spatial segregation of faunal groups corresponded closely with clines in depth, distance from shore, and substrate composition. As these parameters were closely linked, a single determinant of the faunal associations could not be identified. The species which made up each faunal association may have adapted to the environmental conditions which 
prevailed at those sample sites. Therefore, there must have been sufficient environmental variation in the $70-\mathrm{km}$ transect from the shore to the reef to support the segregated faunal groups identified.

Dredge (1989) examined the trawl fauna from the same inter-reef sites and found very little similarity with the true reefal community described by Russell (1983), despite sampling stations being as close as $0.5 \mathrm{~km}$ to reefs. This suggests that other physical features such as sediment type, and not simply proximity to the reef, are the key determinants of the distribution of these benthic fauna. This contention is supported by the work of Somers (1987) who showed that the distribution of penaeid prawns was influenced by both sediment composition and depth in the Gulf of Carpentaria. Macrobenthos community composition correlated well with sediment data in New Caledonia (Chardy et al. 1988).

Depth-delineated community zonation has been identified for Central Great Barrier Reef waters (e.g. Done 1982; Williams 1982). Birtles and Arnold (1989) found that a major separation of mollusc and echinoderm communities occurred between 22 and $26 \mathrm{~m}$ depth. They also reported this depth delineation for crustaceans, bryozoans, demersal fishes, ascidians and algae (Birtles and Arnold 1983). Our nearshore sites (1 and 2) were delineated from offshore site groups in a similar way. Birtles and Arnold (1983) found, as we did, that their offshore sites further differentiated into two groups. Birtles and Arnold (1989) believed that abundant coral rubble and algae at their middle-shelf sites (inshore zone) supported a higher diversity and abundance of echinoderms and molluscs than elsewhere. Their faunal spatial zones corresponded with zones based on sediment characteristics (Belperio 1983) and when reported had remained stable for at least 6 years.

Maxwell's (1968) sediment studies of the Great Barrier Reef described a 'nearshore' (0-9 m depth) and an inner-shelf zone (9-37 m depth). Watson and Goeden (1989) found a correspondence between depth, sediment particle size and carbonate content (after Maxwell 1968) with zones or site assemblages. Rainer and Munro (1982) found three cluster site groups: nearshore (2-5 m depth), shallow offshore (6-14 m depth) and deep offshore (15-35 $\mathrm{m}$ depth) when they observed abundances of demersal fish and cephalopods in the Gulf of Carpentaria. They related these zones to physical factors such as depth and salinity, and found, as our study confirms, that such zones tended to grade into one another, often shared many species, and did not always remain constant through time.

Analysis of spatial differences was dominated by the strong differences between site 1 and site 2, and between these sites and all others. Differences between the midshelf and inter-reef site groups were minor by comparison.

Analysis of temporal patterns in the fauna demonstrated both seasonal patterns ('wet' and 'dry' season faunal associations) and year-to-year variation between 1985 and 1986 . Apparent separation in these groupings between the two study years can be explained by substantial variation in the catch of some faunal groups between years as described above.

Significant temporal variation has been reported in the structure of reef fish assemblages at the local scale (Williams 1986). Watson (1984) reported that significant changes occurred in the abundance and relative dominance of some families of tropical demersal fishes through a period of several months. These authors have suggested that the constancy of spatial community patterns cannot be assumed.

Rainer (1984) reported seasonal patterns in catch rate and species richness per site in Gulf of Carpentaria trawl fauna, with highest values found nearshore in summer, and offshore in autumn and winter. He believed that these changes were associated with the movements of inshore species to deeper water at times of high temperature and reduced salinities. Many species caught in benthic trawl gear are, however, small and slow-moving, otherwise they would not be caught. They appear to be distributed along, and perhaps constrained by, such physical gradients as depth, sediment particle size and carbonate content (Watson and Goeden 1989). The largest source of seasonal variability in community structure is likely to be recruitment variability rather than mass migrations of the relatively immobile adult forms. It is possible that smaller species, presumed to be slower moving, are 
most affected by seasonal variability in habitat. Ward and Rainer (1988) found that most decapods that exhibited seasonal variability were smaller than those whose numbers remained relatively stable over time.

Rainer (1984) reported that seasonal changes in abundance were greatest in the estuarine species. Nearshore coral communities also showed greater seasonal variation than those offshore. These nearshore coral communities were also the most affected by periods of reduced salinity, increased siltation and possibly nutrient enrichment, all resulting from the outflows of nearby large rivers (Done 1982). Well-defined onshore-offshore salinity gradients have been described for the Central Great Barrier Reef region which correspond to the two distinctive 'wet' and 'dry' seasons (Brandon 1973).

We expected to find seasonal variation corresponding to the tropical 'wet' and 'dry' seasons in nearshore communities, with offshore communities remaining comparatively unaffected. Offshore communities might, however, be affected by other seasonal events such as the cross-shelf intrusion of nutrient-rich water from adjacent deeper areas. Williams et al. (1988) observed the latter effect primarily in summer when blooms of diatoms were associated with this upwelling season. Watson and Goeden (1989) found that changes in species abundances between the 'wet' and 'dry' seasons caused 'transitional' sites to change their affiliation between the 'inshore' and 'inter-reef' site groups.

In the present study there was little clear pattern in the abundance of species between the 'wet' and 'dry' seasons (Table 6). There were, however, higher abundances in the 'wet' season than in the 'dry' season for some species characterizing the nearshore groups (Table 5). Examples of this were $A$. pleuronectes, $C$. truncata, and $T$. theraps. Though the effect of summer rains may influence the abundance of some inshore species, a causal relationship cannot be assumed in the absence of confirmatory data.

In May 1985, trawl sampling occurred more than 8 days after the new moon because of adverse weather. Night-time illumination from the moon at this time was considerably brighter than in the other 23 months of samples. This could explain why these samples formed a separate temporal group (Fig. 6).

An insight into the spatial and temporal variability of benthic communities is a prerequisite in the interpretation of research on the effects of trawling in the Great Barrier Reef Marine Park. In addition to socio-economic factors, management zonation of the Park must consider the underlying spatial structure of the benthic community. Only with continued investigation into the natural range of variability in these communities can we hope to differentiate the effects of man's activities.

\section{Acknowledgments}

Our thanks to K. Derbyshire, Dr C. Jones and J. Keating for their sustained assistance; we also thank the crew of the research vessel 'Gwendoline May' and the staff of the Queensland Museum for their invaluable technical assistance. We are grateful for the valuable comments by R. Garrett, J. Mellors and the referees. This work was supported by grants from the Great Barrier Reef Marine Park Authority and the Fishing Industry Research Trust Account fund to M. Dredge.

\section{References}

Belbin, L. (1988). 'PATN (Pattern Analysis Package) Reference Manual.' (CSIRO Div. Wildlife and Rangelands Res.: Canberra.)

Belperio, A. (1983). Terrigenous sedimentation in the Central Great Barrier Reef lagoon: a model from the Burdekin region. Bureau of Mineral Resources Journal of Geology and Geophysics 8, 179-90.

Birtles, R. A., and Arnold, P. W. (1983). Between the reefs: some patterns of soft substratum epibenthos on the Central Great Barrier Reef shelf. In 'Proceedings of the Inaugural Great Barrier Reef Conference'. (Eds J. Baker et al.) pp. 159-63. (James Cook University Press: Townsville.)

Birtles, R. A., and Arnold, P. W. (1989). Distribution of trophic groups of epifaunal echinoderms and molluscs in the soft sediment areas of the Central Great Barrier Reef shelf. In 'Proceedings of the 6th International Coral Reef Symposium'. (Ed. J. H. Choat.) Vol. 3. pp. 325-32. 
Brandon, D. E. (1973). Waters of the Great Barrier Reef Province. In 'Biology and Geology of Coral Reefs, Vol. 1'. (Eds O. A. Jones and R. Endean.) pp. 187-232. (Academic Press: London.)

Bray, J. R., and Curtis, J. T. (1957). An ordination of the upland forest communities of southern Wisconsin. Ecological Modelling 27, 325-49.

Cannon, L. R. G., Goeden, G. B., and Campbell, P. (1987). Patterns of community zonation in Great Barrier Reef waters. Memoirs of the Queensland Museum 25, 45-70.

Chardy, P., Chevillon, C., and Clavier, J. (1988). Major benthic communities of the south-west lagoon of New Caledonia. Coral Reefs 7, 69-75.

Courtney, A. J., and Dredge, M. C. L. (1988). Female reproductive biology and spawning periodicity of two species of king prawns, Penaeus longistylus Kubo and Penaeus latisulcatus Kishinouye, from Queensland's east coast fishery. Australian Journal of Marine and Freshwater Research 39, 729-41.

Dinesen, Z. D. (1983). Patterns in the distribution of soft corals across the Central Great Barrier Reef. Coral Reefs 1, 229-36.

Done, T. J. (1982). Patterns in the distribution of coral communities across the Central Great Barrier Reef. Coral Reefs 1, 95-107.

Dredge, M. C. L. (1989). Bycatch from the central Queensland prawn fisheries. 1: The prawn fisheries, species composition and site associations from the bycatch. Fisheries Research Branch, Queensland Department of Primary Industries, Technical Report FRB 88/04.

Faith, D. P., Minchin, P. R., and Belbin, L. (1987). Compositional dissimilarity as a robust measure of ecological distance. Vegetatio 69, 57-68.

Flint, R. W., and Younk, J. A. (1983). Estuarine benthos: long-term community structure variations, Corpus Christi Bay, Texas. Estuaries 6, 126-41.

Folk, R. L. (1974). 'Petrology of Sedimentary Rocks.' (Austin University Press: Texas.)

Jones, C. J., and Derbyshire, K. (1988). Sampling the demersal fauna from a commercial penaeid prawn fishery off the central Queensland coast. Memoirs of the Queensland Museum 25, 403-15.

Lance, G. N., and Williams, W. T. (1977). Attribute contributions to a classification. Australian Computer Journal 9, 128-9.

Maxwell, W. G. H. (1968). 'Atlas of the Great Barrier Reef.' (Elsevier Scientific Publishing Company: Amsterdam.)

Rainer, S. F. (1984). Temporal changes in a demersal fish and cephalopod community of an unexploited coastal area in northern Australia. Australian Journal of Marine and Freshwater Research 35, 747-68.

Rainer, S. F., and Munro, I. S. R. (1982). Demersal fish and cephalopod communities of an unexploited coastal environment in northern Australia. Australian Journal of Marine and Freshwater Research 33, 1039-55.

Riesen, W., and Reise, K. (1982). Macrobenthos of the subtidal Wadden Sea: revisited after 55 years. Helgolander Meeresuntersuchungen 35, 409-23.

Russell, B. C. (1983). 'Annotated Checklist of the Coral Reef Fishes in the Capricorn-Bunker Group, Great Barrier Reef, Australia.' (Great Barrier Reef Marine Park Authority: Townsville.)

Sale, P. T. (1978). Chance patterns of demographic change in populations of territorial fish in coral rubble patches at Heron Reef. Journal of Experimental Marine Biology and Ecology 34, 233-43.

Somers, I. F. (1987). Sediment type as a factor in the distribution of commercial prawn species in the western Gulf of Carpentaria, Australia. Australian Journal of Marine and Freshwater Research 38, $133-44$.

Watson, R. A. (1984). Trawl fish composition and harvest estimates for the Gulf of Papua. Report No. 84-01. (Dept of Primary Industry: Port Moresby.)

Watson, R. A., and Goeden, G. B. (1989). Temporal and spatial zonation of the demersal trawl fauna of the central Great Barrier Reef. Memoirs of the Queensland Museum 27, 611-20.

Ward, T. J., and Rainer, S. F. (1988). Decapod crustaceans of the North West Shelf, a tropical continental shelf of north-western Australia. Australian Journal of Marine and Freshwater Research 39, 751-66.

Williams, D. McB. (1982). Patterns in the distribution of fish communities across the Central Great Barrier Reef. Coral Reefs 1, 35-43.

Williams, D. McB. (1986). Temporal variation in the structure of reef slope fish communities (Central Great Barrier Reef): short term effects of Acanthaster plancii infestation. Marine Ecology Progress Series 28, 157-64.

Williams, D. McB., Dixon, P., and English, S. (1988). Cross-shelf distribution of copepods and fish larvae across the Central Great Barrier Reef. Marine Biology 99, 577-89. 